\title{
The Kosovo War in a Constructivist Perspective
}

\section{Frederic Labarre *}

\section{Introduction}

This case study supposes that the Kosovo War can best be explained by the application of a constructivist approach to international relations. The case made here, based on the postulate that realism remained a dominant tool for conceiving of international relations and formulating policy until the end of the Cold War, is that constructivism has become a complement or an answer to a realist theory that was unable to explain the peaceful end of the Cold War. As a result, constructivism became an attractive explanation for international relations. The hypothesis tested here is that the Euro-Atlantic community has blessed waging war on a "deviant" state to preserve the changes brought about by the collapse of bi-polarity. More precisely, the Euro-Atlantic community has adopted a realpolitik solution to preserve the benefits of constructivist international relations. This thus suggests that a constructivist outlook is not only useful for explaining the Kosovo war, it is also part of the policy framework of the leading powers.

First, I will briefly critique the realist approach, and-relying on its founding text, The Prince, by Niccolò Machiavelli-show that a "traditional" interpretation of this theory carries the seeds that make constructivism a viable alternative, if not a complement to realism. We socially construct threats just as much as we decide to cooperate. This article therefore obscures the opposition between constructivism and realism. It treats the subscription to and application of realist principles as normative and culturally motivated, and does the same for constructivist principles. ${ }^{1}$ I then proceed with a brief description of the concepts underlying constructivism, and illustrate how these concepts can be reconciled with indicators found in the case study.

In the second part of the essay, I give a chronological description of the Kosovo War, encompassing the diplomatic maneuvers that led to the war and to its resolution. In this section, it will be useful to recall that constructivism was part of the zeitgeist of the 1990s. I conclude by discussing the contradiction between the optimistic spirit of constructivism and the "realistic" decision to launch the campaign against Serbia. The resulting irony is that the safeguard of the "new world order" is the dominant interest of the international community, because it is the embodiment of the change which itself is the expression of constructivism. Therefore, states-alone or in concert-declare war under conditions that realists would not recognize as being in their national interests, but are nevertheless interpreted as power-driven, save that power is applied for the preservation of the new status quo.

Frederic Labarre is a Ph.D. Candidate at the Royal Military College of Canada.

Ronald Jepperson, Alexander Wendt, and Peter J. Katzenstein, "Norms, Identity, and Culture in National Security," in The Culture of National Security: Norms and Identity in World Politics, ed. Peter J. Katzenstein (New York: Columbia University Press, 1996), 33. 


\section{Theoretical Underpinnings}

\section{Traditional Realism: The Source of Constructivism?}

This section presumes that the reader is familiar with the basic principles of realist theory, namely that power-seeking, anarchy, and inherent human wickedness are prevalent. The space is lacking to make an in-depth investigation of the connection between realism and constructivism, yet a quick foray into its traditional thinking will show that realism carries some of its influences into constructivism.

Niccolò Machiavelli's short treatise on power and politics-The Prince-is widely regarded as the seminal text of realist statecraft. Machiavelli's work differs from others precisely because, by his own admission, he does not examine utopian solutions to the problems of government, but rather studies government as it is really practiced. $^{2}$ Whereas the fantasies of a Plato or Socrates are purely normative, The Prince is empirical. Machiavelli's prince sees power as essential, and has no qualms about its use. Yet we will see that the logic of power is not inescapable. Dougherty and Pfaltzgraff trace a brief evolution of realist theory from Machiavelli until the early twentieth century, which shows a number of analytical loopholes permitting the future elaboration of a constructivist approach to international relations. ${ }^{3}$ For example, Thomas Hobbes' remedy against the state of nature is tantamount to world government, a choice antithetical with realistic self-help and notions of the balance of power. Hegel "elevated the position of the state" more than any other philosopher, but it doesn't mean his conclusions were correct; ${ }^{4}$ the idea that the state has an objective reality is patently false. The existence of the state is subjective; that is, it is a human construct built upon a structure of human interactions, and states, having acquired their "individual totality" by this action, are also related based on human choices. ${ }^{5}$ Humans choose to live in society or not. Their societies decide what kind of relations they will have. They are not totally or permanently conflicting. Finally, Weber's acknowledgement of the absolute ethic of conviction and its antithetical ethic of responsibility shows that the logic of power in human and international relations is a matter of choice. These are only a few of the criticisms that can be leveled against the seemingly inescapable logic of power and anarchy in realist theory.

The pessimism of the postwar years was spawned by a resurgently aggressive Soviet Union and the experience of a second devastating war in less than a generationexperiences that were concordant with a vicious and uncompromising view of international relations. Hans Morgenthau suggested that "abstract moral principles cannot be universally applied to specific political actions." ${ }^{6}$ Realist theory is generally doubtful

2 Niccolò Machiavelli, The Prince (1515), trans. W.K. Marriott (London: J. M. Dent and Sons, 1908), Ch. 15.

3 James E. Dougherty and Robert L. Pfaltzgraff, Jr., Contending Theories of International Relations: A Comprehensive Survey, $5^{\text {th }}$ ed. (New York: Longman, 2001), 69-71.

Ibid., 70.

6 Dougherty and Pfaltzgraff, Contending Theories, 71. 
of the ability of human behavior to be influenced, because "human nature is flawed, power-seeking and otherwise imperfect." This resonates perfectly with Machiavelli, who stated: "the wish to acquire is in truth very natural and common." ${ }^{8}$ But in his examination of French King Louis XII's adventures in Italy, he wrote that the King has made six errors, three of which are attributable directly to realist thought (or prudent policy-making): he destroyed the minor powers and increased the strength of one of the greater powers in Italy (Pope Alexander VI); he brought in a foreign power (Spain); and he reduced Venice, which alone could have served as a counterweight to the ambitions of other actors. ${ }^{9}$ If talent and good judgment are not always equally distributed among statesmen, this does not otherwise affect the universality of rationality; in other words, policy choices do not impose themselves. King Louis, according to realist principles, sought to reduce the small powers because "the weak must suffer what they must" (to paraphrase Thucydides). So why did Machiavelli consider this a mistake? If the pursuit of power is both a means and an end, as modern realism suggests, then this solution would seem to make sense. ${ }^{10}$

If many were surprised that the King would seem too willing to yield or otherwise cooperate with the Church, it was because of a quid pro quo with the Pope, who promised to annul the King's marriage if he helped him recover Romagna. Realism would have urged the strongest to become stronger still by not empowering an already powerful adversary. In other words, the logic of power is not always prevalent, and I would wager that this is because anarchy is not always complete; the Church may have held enough legitimacy for Louis that he would have insisted on Papal blessing for the annulment of his marriage. This also means that the interests of the state are not objective; they are sometimes confused or replaced by human interests. Power is not the only interest. There are other examples where human purpose preceded political decision. In Machiavelli's view, a Prince can either maintain the laws of a city he has annexed, reside there, or ruin it. ${ }^{11}$ Here the use of princely power is differently applied. Machiavelli also suggests that there are moral limits to the use of force: "barbarous cruelty and inhumanity with infinite wickednesses do not permit [...] to be celebrated among the most excellent men." ${ }^{2}$ He also advises to do "wrong" or not according to necessity. Again, the Prince has a choice, even if necessity is objective. ${ }^{13}$ In Chapter 18 , he writes that the law is insufficient to attain or maintain power. ${ }^{14}$ He never states that force should replace the law, and since those laws can be modified, it is manifest proof that humans can live either according to force or to law, which raises doubts re-

\footnotetext{
Ibid., 71.

Machiavelli, The Prince, Ch. 3.

Machiavelli, The Prince, Ch. 3.

10 See John J. Mearsheimer, The Tragedy of Great Power Politics (New York: Norton, 2001).

11 Machiavelli, The Prince, Ch. 5.

12 Ibid., Ch. 8.

13 Ibid., Ch. 15. "Wrong” here is intended as "immoral," and does not denote an erroneous decision.

14 Machiavelli, The Prince, Ch. 18.
} 
garding the validity of inherent anarchy. Indeed, Machiavelli acknowledges the possibility of change, which is anathema ideologies that insist on the permanence of human wickedness: "the Prince must have a mind ready to turn itself accordingly as the winds and variations of fortune force it..."15 Finally, his "exhortation to free Italy from the barbarians" is purely emotional, and has no bearing on notions of "princely," "republican," or "Italian" strategic interests in the realist sense. ${ }^{16}$ Machiavelli wants a return to a previous Italian identity akin to that of ancient Rome. His motivation to write The Prince was a desire for change. His dedication of the book to the Medici family further shows that he was seeking an end to the anarchy that was gripping Italy. If anarchy can come to an end, can it really be called anarchy, or is it "what states make of it?"17

\section{Constructivism and Regime Theory}

The preceding discussion supports the suggestion that identities and interests of actors are not exogenously given, or consequences of the anarchy of the system, or dependent upon the distribution of power within it. "[Any] social system confronts each of its members as an objective social fact that reinforces certain behaviors and discourages others. Self-help systems, for example, tend to reward competition and punish altruism." 18 In other words, self-help as conceived in realist theory is a social construct created by the agents of the system — or, at least, the conditions that lead to self-help are not objective. It is actors' identities and corresponding interests that determine the character of their relations, not the fact that there is no overlord among them. Survival may not always depend on the absolute pursuit of power (as in a "minimax" solution in game theory, for example), but on occasional accommodation and cooperation. Social scientists have noticed that, whereas defection from cooperation is always an attractive policy for "punctual" encounters in the state of nature, the structure of relations is rather based on repeated interactions. ${ }^{19}$ Thus, I would argue that the topic of power is classical realism, and that the need for cooperation in neo-liberal and institutionalist theory are both socially constructed. We therefore need to distinguish between each version of the construct and from other neo-realist and neo-liberal theories. This is why in the rest of this essay I call "realist constructivism" the policies and events that indicate reliance on self-help, and invoke respect for the traditional attributes of statehood (i.e., a Weberian outlook, where the state in an anarchical environment is the sole arbiter of what goes on within its borders). This is opposed by what I call "liberal constructivism," which refers to approach that holds that policies and events are grounded in norms and rules as defined by international actors and the various institutions they create. This modifies the concept articulated by Nye and Keohane (later refined by

${ }^{15}$ Machiavelli, The Prince, Ch. 18.

16 Ibid., Ch. 26.

17 Alexander Wendt, "Anarchy is What States Make of It: The Social Construction of Power Politics,” International Organization 46:2 (Spring 1992): 391-425.

18 Ibid., 411.

19 James A. Caporaso, "International Relations Theory and Multilateralism: The Search for Foundations,” International Organization 46:3 (Summer 1992): 606-7. 
Wendt) because it grants a more prominent role to a realism which, if it is classically considered, explains why there can be cooperation (rather than dominance) in asymmetric power relations and defection in repeated "games."

This distinction postulates no difference between constructivist, positivist, neo-liberal, or regime theory, or theories of institutionalism, functionalism, or multilateralism. There was a debate, early in the 1990s, as to the nature of multilateralism and institutionalism, but I think the nuanced differences between these concepts are rather insignificant for our purposes here; ${ }^{20}$ as they all explain state behavior through socially constructed norms, rules, and principles that are more (laws, treaties, international organizations) or less (customs, habits) formally made operational. ${ }^{21}$ This definition, given by Robert O. Keohane, will suffice to illustrate our point, and accurately represents the world as it evolved between the end of the Cold War and the beginning of the post9/11 era in which we now live. ${ }^{22}$

During this period, a wealth of international organizations were either born or grew to such a degree to support newfound optimism; in 1991, the Maastricht Treaty gave rise to the European Union as we now know it; in 1994-95, the General Agreement on Tariffs and Trade became the World Trade Organization, the Conference on Security and Cooperation in Europe became an Organization (OSCE); and the arrival of several important anniversaries (among which were the fiftieth anniversaries of the United Nations in 1995 and of NATO in 1999) reminded public opinion and policy circles that there were instruments ready to support the decisions of states to adopt a more cooperative stance. These international institutions were in alignment with trade regimes that stood to globalize economic relationships, now that the planet was operating under the same free market model. Certainly, all these institutions are embedded with norms and rules, and the principle is cooperation.

What these norms and rules do is usher an element of predictability into international relations. They never, however, limit the sovereign rights of states to dispose of themselves (or other institutions); the case of the Western European Union, the precursor to NATO, comes to mind. It was absorbed into the EU in 1999-2000, and this represents the sovereign decision of member states to let this organization disappear.

20 Ibid., 602, for multilateral vs. multilateralism; see also John Gerard Ruggie, "Multilateralism: Anatomy of an Institution,” International Organization 46:3 (Summer 1992): 570, where "multilateral" qualifies "institution" and where "multilateralism" is an institution.

21 See Robert O. Keohane, "Multilateralism: An Agenda for Research,” International Journal 45 (Autumn 1990): 731-64.

22 Sean Kay, "NATO, the Kosovo War and Neoliberal Theory," Contemporary Security Policy 25:2 (August 2004): 252. See also, in support of the notion of the development of "civil society,” Craufurd Goodwyn and Michael Nacht, eds., Beyond Government (Boulder, CO: Westview Press, 1995). The 1990s reflected a popular and generalized relief from the balance of terror which, once lifted, signaled to large swaths of global civil society that the time was ripe for activism in favor of disarmament, environmental responsibility, an increase in foreign aid and, in general, more reliance on international organizations such as the UN and the OSCE to solve problems in the field, with the assistance of increasing numbers of private non-governmental organizations. 
Other forms of rules and norms emerged. The North Atlantic Free Trade Agreement (NAFTA) is not an organization, but rather a treaty that delimits the geographical and functional areas of trade in goods and services, buttressed by the World Trade Organization, as well as by the fact that other principles-namely that of good-neighborly relations - had operated in the region on a habitual basis since the early nineteenth century for Canada, and since the early twentieth for Mexico. Certainly, the Dayton Peace Accords that put an end to the first Balkan war of the 1990s figures as a norminstituting treaty. The fact that the signatories agreed to the terms of the DPA under duress does not change the fact that the option to resolve issues peacefully rather than via self-help was always open to them. The aim of such an effort is to affect the practices of the belligerents in peace so that their behavior manifests a change in interest and identity. Certain treaties, such as the Anti-Ballistic Missile (ABM) Treaty (repealed in 2002), are covenants that codify realist principles.

Finally, ideas such as "good-neighborly relations" and "confidence building measures" are international bureaucratic concepts that underpin the practice of regime creation. ${ }^{23}$ It is under such conditions that certain dyads-such as the United states and Canada, Switzerland and its neighbors, the Scandinavian countries, to name only a few-have coexisted for centuries. Both concepts not only verify regime theory, they seek to apply it. In sum, the examples given above, and the definition unifying them are sufficient to give a constructivist account of the Kosovo War, which can be interpreted as nothing less than a clash between what Stefan Popov describes as "human rights vs. sovereignty," 24 or what Filip Tesar sees as a dilemma between the "pragmatic and the just” 25 - or, as we see it here, between Serbo-Albanian realist constructivism and Western liberal constructivism as it has emerged since $1989 .{ }^{26}$ But these values have never been, and likely will never be, universal.

The end of the Cold War has had profound consequences for the nation-state. Robert Cooper argues that, for the most advanced liberal democracies, this has meant an erosion of sovereignty in favor of regimes, rules, norms of behavior, and the inclusion of non-traditional subjects of security, like the environment, human rights, and so on. But many states, like Serbia, have remained "modern"-tied to traditional notions of sovereignty, non-interference, and holders of classical realist viewpoints when considering state security. Still more, released from their superpower sponsors, fell into "pre-modern" status, where the state is unable to secure its own borders, and where sovereignty has dissolved in favor of the small group. There, survival is the most

${ }^{23}$ NATO, Study on Enlargement (Brussels: NATO Office of Information and Press, 1995), lists "good-neighborly relations" as one of the concrete measures that aspiring NATO members had to take to be worthy of consideration. "Confidence building measure" is a recurrent concept in UN and OSCE terminology. Stefan Popov, "NATO Expansion: From Collective Defence to Collective Security,” Perspectives 13 (1999): 66.

25 Filip Tesar, "What has NATO Achieved in Kosovo?” Perspectives 13 (1999): 56.

26 John Williams, Legitimacy and the Rise and Fall of Yugoslavia (London: McMillan, 1998), 41. 
pressing concern, and whatever norms of good national or international conduct we may hold are but chaff in the wind. ${ }^{27}$

Thus we see newly "modern" Serbia trying to hold on to its territorial integrity, while Kosovo, trying to be modern, flirts dangerously with pre-modernity. Above it all, the post-modern (only incompletely so) Euro-Atlantic region is trying to come to grips with the clash of three perceptions of the state, and two corresponding interaction principles: constructivism and savage realism.

It was in this context that the saga of Kosovo unfolded and revealed two paradoxes, one general, and one particular. The particular paradox is that Kosovar Albanians succeeded in internationalizing the crisis so as to bolster their separatist claims. In other words, they are seeking the help of international multilateral actors to validate their realist constructivist norm of sovereign self-determination. To them, multilateralism is instrumental; they use institutional norms and rules as a self-help tool. The only consistent actor in this drama is Serbia, obstinate in the preservation of its Weberian/ Westphalian privileges of absolute sovereignty and norms of non-interference in internal matters. For John Williams, this is logical:

Only by controlling their own State can [national self-determination movements] gain the protection of international law and the rules and norms of international society.... It has been argued that this sort of communitarian basis for statehood is strongly reflected in Realism... ${ }^{28}$

The general paradox is that the international community, here represented by multilateral institutions, is composed of legitimate members who have a vested interest in both the territorial status quo and the promotion of cooperative international relations, and in peaceful settlement of disputes. In other words, there is an uncomfortable oscillation between the preservation of realist constructivist norms of sovereignty and noninterference and the preservation of liberal constructivist norms of human rights and obedience to rules of good conduct. As we will see, an international organization of nineteen members needed to violate its rules in order to better preserve them.

\section{Chronology and Theory Application}

Any historical depiction of the scope of conflict in the Balkans is notoriously daunting. Yet, since every conflict has its context-which itself begs a historical analysis of a region that "has more history than it can consume"-the exercise will inevitably be incomplete. This article considers Serbia's decision to apply coercive pressure on the population of one of its provinces, and the international response to Serbia's actions. Thus the start of the "Kosovo War" occurred when ethnic Serb forces began attacking

${ }^{27}$ Christopher Dandeker, "The End of War? The Strategic Context of International Missions in the $21^{\text {st }}$ Century," in Eight Essays in Contemporary War Studies, ed. Magnus Christiansson (Stockholm: Förvarshögskolan, 2007), quoting Robert Cooper, The Breaking of Nations: Peace and Order in the $21^{\text {st }}$ Century (New York: Atlantic Monthly Press, 2004).

28 John Williams, Legitimacy and the Rise and Fall of Yugoslavia, 33. Those who have argued this point are Palan and Blair in the Review of International Studies 19 (1993). 
Kosovar Albanian militias and engaging in what came to be termed "ethnic cleansing." The Kosovo War was at the same time a contest of will between the Republic of Serbia and the international community, which issued warning after warning, which turned to coercion when the Rambouillet negotiations failed in early 1999. It concluded with the capitulation of Serbia after NATO's air campaign in June of that year.

As was mentioned above, this conflict cannot be divorced from its convoluted context. It is relevant to say that Kosovo bears acute significance in the heritage of Serbia; it was on the fields of Kosovo, in late June 1389, that the nascent Serb people were defeated by the Ottoman Turks. This founding myth has never been forgotten by the Serbs and, on the occasion of a clash between ethnic Serbs and Kosovar Albanians in Kosovo as early as 1987, future Serbian president Slobodan Milosevic first tasted the potency of nationalistic demagoguery by assuring the amassed Serbs "you will not be beaten (again).,29

It is tempting to only present a case at the group level of analysis, confident that the Kosovo War was essentially a contest between the in-group (Serbs) and the out-group (Kosovar Albanians). However, the analysis would break down once the NATO variable was introduced to the equation. A multinational organization like NATO makes decisions based on consensus. Group-level analysis would therefore "expect" the Greeks to support the Serbs because the Turks would support the Kosovar Albanians, creating a stalemate within the organization. There is evidence that some Greek interests would have in fact leaned in favor of the Kosovar Albanians (and thus would not have vetoed coercive diplomacy). ${ }^{30}$ Neither can hegemonic theory help us here; the United States was showing clear and well-documented signs of intervention fatigue in the late 1990s. Therefore, the decision to intervene must have been based on a more universal concept of identity. As we will see, constructivism can help explain the preNATO portion of the Kosovo conflict, the internationalization of the conflict, as well as NATO's ultimate decision to intervene.

29 International Criminal Tribunal for Yugoslavia (ICTY), Transcripts from the Milosevic Trial (The Hague, Netherlands, 2 February 2005), 35943-48; available at http:/www.un.org/icty/ transe54/050209IT.htm. This event has also been recorded on video, and can be seen in the BBC documentary "Death of Yugoslavia” (1995), produced by Nicholas Fraser and Brian Lapping. It is unclear whether the word “again” was actually pronounced. Despite Mr. Milosevic's attempts at setting the translation records straight, the fact remains that his words inflamed passions in a way designed to guarantee him political support.

30 Filip Tesar, "What Has NATO Achieved in Kosovo?" 56. The realist inclination of certain authors from former Warsaw Pact countries is evident in their choice of explanations and indicators of support for or against the Kosovo air strikes. See Ladislav Cabada and Martin Ehl, “The Kosovo Crisis and the Prospects for the Balkans,” Perspectives 13 (1999): 25. 90 percent of Greeks opposed the air strikes, yet the government retained solidarity with the Alliance, and the Italians went along in spite of the electoral risk the decision posed to the d’Alema government. 


\section{The Federal Republic of Yugoslavia Against Kosovar Separatists}

Serbia's position regarding Kosovo depended upon the need for Mr. Milosevic to make good on his promise to protect the Serb minority in Kosovo, which was until June 1989 an autonomous province of Yugoslavia. According to Stefan Troebst, Milosevic had to go back on previously-made reconciliation gestures (in 1996) when he was confronted by an ultra-nationalist opposition in Belgrade. ${ }^{31}$ When the Dayton Peace Accords were signed in December 1995, the only mention of Kosovo was linked to recognition of the former Republic of Yugoslavia and its participation in international regimes and organizations. ${ }^{32}$ This means that Milosevic (the lone Serb negotiator in Dayton) must have committed - either voluntarily or not - to an institutional worldview, in the sense that he wished for Serbia's participation in international institutions. It is in this light that we must explain the overtures made to the Kosovar Albanians in 1996. Yet, we could say that the Serbian parliamentary opposition did not share this viewpoint. Furthermore, their position — and the decision by Mr. Milosevic to send militias (and the notorious proto-terrorist “Arkan”) back into Kosovo-has as much to do with the logic of political survival as the decision by Kosovar Albanians to challenge the policy of non-violent resistance of Kosovo's Dr. Ibrahim Rugova. Serb “democracy” pushed Milosevic to the extremes at the same time that the Kosovar Albanians were becoming frustrated with moderation. ${ }^{33}$ The fact remains that the decisions both of Mr. Rugova and Milosevic to initially try to keep tensions to a minimum were made independent of the logic of power politics. It was their respective constituencies that had non-cooperative viewpoints. The fact that both constituencies succeeded in making each of them adopt self-help policies shows that there is the possibility of oscillation between cooperative and non-cooperative behavior. Not only is the Serb leadership's desire to join the "international community" through its institutions a sign of the potency of constructivism, so is the shift between choices predicated by identity.

The brief ethnic conflict between opposing Serbs and Kosovar Albanians was thus a conflict of identity, where the "other" was socially constructed as threatening. The reasons given by the Serb side for this construction appear compelling: astronomically rapid demographic growth in the Albanian population, coupled with chronic economic stagnation, on top of being the ethnic majority in the province where the Serb nation's foundation myth had its roots. The rhetoric surrounding this myth (based on the defeat of Serb forces by Ottoman Turks in June 1389) was part of the social construction of policy. Mr. Milosevic's address on the occasion of the $600^{\text {th }}$ anniversary of the battle

31 Stefan Troebst, Conflict in Kosovo: Failure of Prevention? Analytical Documentation, 1992-1998, ECMI Working Paper \# 1 (Flensburg: European Centre for Minority Issues, 1998), 20. See also Ladislav Cabada and Martin Ehl, "The Kosovo Crisis and the Prospects for the Balkans,” Perspectives 13 (1999): 23; and Eric D. Gordy, "Why Milosevic Still?” Current History (March 2000): 100.

32 Troebst, Conflict in Kosovo, 19.

33 Dick Leurdijk and Dick Zandee, Kosovo: From Crisis to Crisis (Aldershot, U.K.: Ashgate, 2000), 22, quoting Miranda Vickers, Between Serbs and Albanians: A History of Kosovo, (London: 1999). 
of Kosovo Polje shows the enunciation of a clear path to conflict: "Today, six centuries later, we are still fighting battles. They are not armed battles, although such things can not yet be excluded." ${ }^{34}$

The Albanian program of separation from Serbia was not a figment of the imagination (although the hope for re-integration with a "Greater Albania" has been shown to be a fantasy). ${ }^{35}$ The political emancipation of the Kosovar Albanians and their lack of any economic outlet in a context where there was clear discrimination against them triggered powerful secessionist tendencies. ${ }^{36}$ The emergence of the Kosovo Liberation Army went hand-in-hand with the appearance of Serbian paramilitaries in Kosovo, in breach of the promises made by Serbia in the Dayton Accords.

In essence, the Serb side had effectively chosen to secure its identity as it was conceived in opposition to the Kosovar Albanians, rather than to re-invent an identity that would see it integrate with international institutions (in other words, an identity rooted in norms-based behavior). It is worth considering whether the Albanians realized that, if this were to occur, they themselves would never achieve independence, and thus sought to push the Serbs toward non-cooperation. Western reluctance at creating a precedent in establishing the independence of Kosovo was understandable, since most nations have communities within their borders that are eager for more advantages, if not outright separation. The only way, therefore, for the Kosovar Albanians to achieve what they wanted was to get the Serbs to depict themselves as not being bound by the rules of humanitarian conduct.

Belgrade and Pristina's attitude towards each other typified a traditional realist contest for survival. The former saw national survival as heavily dependent on the maintenance of territorial integrity, and, indeed, the Milosevic regime may have ultimately been cornered by its own rhetoric - the nationalist claim that Kosovo in particular cannot be let go. Kosovar separatists, for their part, sought full-blown independence. As a result, they could not accede to Belgrade's offers of dialogue (two offers were made in May and June of 1992, both rejected by Kosovar Albanians).

The power of constructivism is revealed not only as a theory, but as a policy approach; Troebst writes that the two sides had been trying to enter into serious dialogue between 1992 and 1996, but each leader's position was made untenable by the political fragmentation within their respective constituencies. This fragmentation reflected the conflict between core international (realist) values of territorial unity and non-inter-

34 Leurdijk and Zandee, Kosovo: From Crisis to Crisis, 8, quoting Vickers.

35 Troebst, Conflict in Kosovo, 18 and 24. Rugova tried his best to avoid a military secession of Kosovo, but the goodwill he garnered in the West triggered resentment at home and ultimately, the creation of the Kosovo Liberation Army (KLA).

36 Leurdijk and Zandee, Kosovo: From Crisis to Crisis, 22-23. It is not the aim of this essay to rehash the facts leading to the Kosovo War between Serbs and Albanians. For a description of the hardships that befell the minority of Albanians during the 1990s, and especially after the DPA, see Leurdijk and Zandee. 
vention, and norms of protection of human rights. ${ }^{37}$ As a result, the best both could achieve was non-binding "Track 2" diplomatic efforts. ${ }^{38}$ In the autumn of 1998, ethnic cleansing began, and the international community, which had shown some well-documented concern since the early 1990s, began to rouse itself.

\section{Internationalization of the Crisis}

Dagmar Skrpec has summarized the period from 1992 until January 1999, which culminated with the failure of the Rambouillet accords, as a decade of warning and a year of diplomacy. ${ }^{39}$ This decade of warnings was a further expression of liberal constructivism by the international institutions, who saw themselves as the legitimate heirs (and, ironically, guarantors) of the post-Cold War state system. The year of diplomacy — which is best illustrated by the content of the Rambouillet accords-stands as a confirmation that the spirit of the times was dominated by the "normalization" of relations, which has come to mean relating to other countries either through international organizations or obeying their rules or the prescriptions of international law. This behavior is the expression of liberal constructivism. Any country choosing to operate outside those norms and rules in pursuit of its own security is openly defying those norms and rules; it is thus defined as a "rogue" state.

The internationalization of the crisis began after attempts at resolving the simmering crisis in Kosovo domestically had failed. It is ironic to see that a province seeking to become a sovereign state (in the traditional realist sense) would become so dependent on multilateralism and international actors. This highlights yet another paradox associated with regime theory and multilateralism, one that makes the distinction between realist constructivism and liberal constructivism more acute. This paradox has to do with whether multilateralism is an instrumental or teleological choice - in other words, whether multilateralism is simply a façade, and a tool of states' egotistical interest, or whether multilateral cooperation is a goal unto itself, undertaken for its own sake.

James Caporaso has written that, "In instrumental theories ... cooperation has been used to mean a process by which states actively adjust their policies to take into account the preferences of others." ${ }^{40}$ Cabada and Ehl have, I think, correctly understood that the "nationalistic fury" of the Balkan Wars "influence both the character of the unification of Europe under the heading of the European Union, and relations between major powers," suggesting that the institutionalization of Europe and the creation of a regime based on rules and norms is a telos, a goal of policy. ${ }^{41}$ Yet there are still power-

37 Marc Weller, “The Rambouillet Conference on Kosovo,” International Affairs 75:2 (1999): 216.

38 Troebst, Conflict in Kosovo, 29-30. “Track 1" refers to official diplomacy, whereas Track 2 concerns NGO-led (and therefore unofficial) efforts.

39 Dagmar Skrpec, "European and American Reactions to Kosovo: The Policy Divide Revisited in the Iraq War,” SAIS Review 23:2 (2003): 94, 98.

40 Caporaso, "International Relations and Multilateralism," 603-4.

41 Cabada and Ehl, "The Kosovo Crisis and the Prospects for the Balkans," 21. 
ful indicators that make certain commentators unable to shake the notion that international institutions are tools of national power. ${ }^{42}$

It seems clear that Kosovar Albanians have sought to generate international goodwill from powerful international organizations simply by acknowledging their role as conflict managers. This is one way to show that they speak the same language of liberal constructivism, in opposition to Belgrade's realist constructivism and language of force. In fact, Kosovar Albanians were really speaking the same language as Belgrade. Their behavior was also diametrically opposed to that of international institutions, not only because some members of the Albanian minority in Kosovo actively endorsed terrorism and political assassinations, but also due to the fact that institutional actors (including the great powers involved in the crisis) saw multilateralism as an end in itself, not as a tool of their own selfish national goals.

And so, for nearly a decade, both international organizations and the Kosovar Albanians were brought face to face with a dilemma: the former intended to maintain Serbia's sovereignty while simultaneously trying to lead the FRY on the path of international law, while the latter sought the very same privileges of statehood. Internationalization of the crisis meant that the principles of non-intervention enshrined in the 1975 Helsinki Final Act would need to play second fiddle to other international documents, such as the 1948 UN Declaration on Human Rights. Both the Final Act and the Declaration on Human Rights are part of the same body of international law, which are rules and norms. Hence the international community had to decide and justify whether it was better to obey the spirit or the letter of those laws. Between Serbia, Kosovo, and the international community, the only actor that managed to solve this evident dissonance was Serbia, which sought to have the principles of non-intervention respected by the international community. ${ }^{43}$ Christopher Lord introduces this caveat, however:

The fundamental problem is one of creating and preserving an international legal order.... Once the Belgrade government authorised these operations [against Kosovo militias], though, it stepped over a threshold which rendered its own actions illegitimate.... Although it is a desperately difficult situation, surely our only legitimate course is to seek to establish an international legal order, so that governments cannot carry out this policy in the first place.... ${ }^{44}$

Belgrade exposed itself to sanctions the minute it could be demonstrated that it did not comply with Article VII (respect for human rights and fundamental freedoms, including freedom of thought, conscience, religion, and belief), Article VIII (equal rights and self-determination of peoples), and Article X (fulfillment in good faith of obligations under international law). ${ }^{45}$

42 Erik Yesson, "NATO and Russia in Kosovo," Perspectives 13 (1999): 15, quoting Philip Zelikow.

${ }^{43}$ Conference on Security and Cooperation in Europe, “Final Act,” Helsinki 1975, Chapter 1, Articles I, III, IV and VI.

${ }^{44}$ Christopher Lord, “Now America Takes Over,” Perspectives 13 (1999): 39-40.

${ }^{45}$ Helsinki Final Act, 1975. 
The liberal character of the international community's position vis-à-vis the FRY is evidenced by the content of its repeated warnings. These warnings sought a multilateral solution for its own sake. A multilateral solution is one that simultaneously validates the role of international organizations as conflict managers and the supremacy of cooperative norms and rules in interstate behavior. It is this behavior that the FRY was so obstinate in resisting; yet, it is also the behavior that the Kosovar Albanians had an interest in encouraging, for it justified the international community siding with them against Belgrade. The international community took for granted that Belgrade wanted to be an integral part of the Euro-Atlantic security architecture, or of other institutional arrangements designed to regulate economic and political exchanges. ${ }^{46}$ But the evidence so far points to a perception by Belgrade of legitimate international relations as state-based, not institution-based. It is for this reason that the policy of linking good Serbian behavior in Bosnia-Herzegovina with re-admittance to the OSCE (then CSCE) as a participant in the summer of 1992 was insignificant; all it offered was a pretext to get completely rid of OSCE observers. ${ }^{47}$ Neither was the U.S. "wall of sanctions"- designed to pressure the Milosevic regime to implement a 1996 Memorandum of Understanding with the Pristina government over education and school curricula-any more effective in getting the Milosevic regime to abide by international standards. ${ }^{48}$

The best that the United Nations General Assembly could do was to "urge" the FRY to "allow the immediate unconditional return of the long-term mission of the Organization of Security and Cooperation in Europe to Kosovo." 49 The UN Security Council effectively left the burden of conflict management to the OSCE, recognizing its contribution to conflict prevention and stability building, and concurred with the relevant General Assembly resolutions by recommending that the FRY "reconsider their refusal to allow the continuation of the activities of the CSCE missions in Kosovo..." and to "cooperate with the CSCE...,"50

46 For example, many resolutions of the European Parliament betray this assumption: "The European Parliament ... aware of the desire of the governments of Serbia and the Federal Republic of Yugoslavia for full diplomatic recognition and for the ending of all sanctions imposed on them by the United Nations ... [will only grant full diplomatic recognition] if a full and satisfactory settlement is reached....” In Official Journal of the European Communities, Future of Kosovo (Rule 92), A4-0054/96 of 18 March 1996. The Parliament also called on the Council of Europe "to make steady negotiations on Kosovo a condition for any further development of the EU's relations with the Federal Republic of Yugoslavia.” In Bulletin of the EU, Parliament Resolution on Kosovo (OJ C 115) of 14 April 1997. The Parliament made a similar call again in October 1997, stating that "future relations with the EU ... [should be] dependent on respect for human rights and positive developments in the situation in Kosovo." See Troebst, Conflict in Kosovo, 64.

Troebst, Conflict in Kosovo, 37.

48 Ibid., 19.

49 “Situation of Human Rights in Kosovo," UN GA Draft Resolution \#A/C.3/52/L.61, 20 November 1997.

50 UN Security Council Resolution S/RES/855, 9 August 1993. 
The CSCE (later OSCE) had taken the lead role early on in the crisis, but most of its diplomatic efforts were spent, between 1993 and 1996, attempting to secure monitoring missions of various durations and to guarantee the safety of monitors. This insistence on the return of verification missions was routinely and successfully frustrated by Belgrade. ${ }^{51}$ In essence, selfish realism was triumphing against liberal constructivist idealism by virtue of the fact that the Helsinki Final Act, which is the basis of the existence of the OSCE, trapped the organization into respecting the principle of non-interference. Belgrade refused to grant OSCE Chairman Van der Stoel a visa to discuss the Kosovo issue up until March $1998 .^{52}$ Until that date, the only thing that the OSCE could do was to repeatedly ask for permission to return to Kosovo, and "express serious concern" over the unrest there. When the Helsinki Final Act was signed in November 1975, it was impossible to predict how public opinion would react to the end of the Cold War. In fact, if the Final Act had hastened the demise of the USSR by stressing its inner contradictions, there could not be an "image" of when the Cold War would be over, nor of how it would end. The OSCE cannot be faulted for the fact that the Final Act codified an understanding of statehood which is realist in nature, and that the pious few references to human rights and self-determination are just as weak and ineffectual as the OSCE itself in reconciling state sovereignty with those concepts.

Moribund, the OSCE had to enlist the help of "competing” security institutions to compel Belgrade to let it act. This was a fateful step, which would see it progressively shunted to the margins of the situation. The Council of Europe called on the FRY to accept the EU's help in conducting a census in Kosovo, urging Serbs to resume negotiations based on "full recognition of, and respect for, the ... rights of the Kosovo Albanians in accordance with Council of Europe principles and instruments," and lastly urged the OSCE to allow FRY participation in its work. ${ }^{53}$

In the end, the Council of Europe could not do much more than the OSCE, not only because it shared the same values and norms as that organization, but also because they shared many of the same members. There is little more to be expected if the only thing that changes is the messenger. Clearly, the problem had to do with the way the message was delivered. The only advantage of this contribution was to show the world that every diplomatic avenue was being exhausted. The exception to the rule of "double condemnation" of Serb repression and Kosovar terrorism came on the occasion of the Drenica massacre, which prompted a delegation of the European Parliament, a body that scarcely two months before had called on the FRY to instantly re-establish the human rights and fundamental freedoms of the Albanian population of Kosovo and had sought to establish a permanent presence to help implement the Belgrade-Pristina Memorandum of Understanding on education. ${ }^{54}$ According to Dagmar Skrpec, it was

51 Troebst, Conflict in Kosovo, 38.

52 Ibid., 40.

53 Council of Europe, Resolution 1077 (1996), Strasbourg, 24 January 1996.

54 Troebst, Conflict in Kosovo, 44-45. 
this massacre that kick-started the "year of diplomacy" and prompted greater involvement of the United States in the crisis. ${ }^{55}$

By 1998, the OSCE had finally managed to negotiate the return of its verification mission, and was calling on the FRY to cooperate with other international organizations, making such cooperation conditional on further integration. ${ }^{56}$ This time, however, the UN Security Council was casting more than a passing glance at the problem. There was recognition that the OSCE was largely incapable of making its message heard, and so the UNSC took hold of its "primary responsibility for the maintenance of international peace and security" and demanded of all parties concerned the "full and prompt implementation of ... agreements [16 October 1998 agreement between FRY and OSCE, and the 17 October 1998 between FRY and NATO, pursuant to UNSC Res 1199/1998] by the Federal Republic of Yugoslavia."57

Yet, there was nothing new under the sun; the UN Security Council, faithful to the ways of the international community, persisted in trying to pressure the FRY in such a manner that international organizations would reap maximum validation for their existence (if ever they were allowed to perform in Kosovo). Calls by the UNSC to have Serbia facilitate the return of refugees in cooperation with the Red Cross and the UN High Commissioner for Refugees reminded all states of their obligations under UNSC Res. 1160, all the while reaffirming the territorial integrity of the FRY. ${ }^{58}$

The Contact Group on Bosnia-Herzegovina, which had been enlarged to include Germany and Italy in 1996, began to consider Kosovo as being linked with the reduction of tensions in Bosnia. ${ }^{59}$ The essence of their concerns and recommendations to Belgrade mirrored those of the UN, OSCE, and other international agencies. The difference is that these were states that actively advocated a solution "in accordance with OSCE standards and the UN Charter," and to implement the Education agreement negotiated in 1996 between Mr. Rugova and Milosevic. ${ }^{60}$ This further demonstrates that the spirit of the times was occupied by an internationalist perspective that Belgrade was purposefully resisting, despite the many reassurances that Serbia's territorial integrity would be protected.

In the end, the only thing the Albanian population of Kosovo could achieve in internationalizing the problem was a promise to have educational reform upheld; they never achieved self-determination in the sense of complete independence from Belgrade. As Tim Judah writes, the Kosovar Albanian policy of peaceful resistance had largely failed to impress the international community, and the Dayton Peace Accords shattered a fragile assumption that Kosovo independence could be achieved. First, the

55 Skrpec, "European and American Reactions to Kosovo," 97.

56 OSCE Permanent Council Decision \#218, 11 March 1998.

57 UNSC Res 1203/1998, 24 October 1998.

58 These principles are repeated in UNSC Res 1199/1988, 23 September 1998, and UNSC Res 1203/1998, 24 October 1998.

59 The Contact Group was made up of France, Germany, Italy, Russia, U.K. and U.S.

60 According to Stefan Troebst, these demands were made three times officially in the space of less than six months. See Troebst, Conflict in Kosovo, 48-49. 
Kosovar Albanian leadership had thought that-unimpeded by the international community-Belgrade would achieve its "Greater Serbia" ambitions, which could create the precedent and excuse for Kosovo to legitimately separate. ${ }^{61}$ This belief underlines yet again their faith in a traditional approach to international relations, where the local and global powers would let Yugoslavia implode, and burn itself out since, after all, realist assumptions foresaw no vital interests at stake for Europe or even the United States that would compel intervention in the region. Yet, as early as 1992, President George H.W. Bush issued a "Christmas Warning” (repeated by President Clinton) ${ }^{62}$ hinting that the United States would intervene in Kosovo "for a safer world, for ... democratic values."

Between the spring and fall of 1998, matters in Kosovo escalated quickly. Dr. Rugova's tactic of non-violence became completely discredited, which allowed the Kosovo Liberation Army-whose nature as a terrorist organization was a matter of consensus from Belgrade to Washington, by way of Moscow — filled the political void. This is what prompted the Serbian regime to launch an ethnic cleansing operation there, which was only stopped once the United states sent Richard Holbrooke (of Dayton fame) to successfully negotiate a withdrawal from Kosovo and the return of OSCE monitors there. ${ }^{64}$ Even if this success seems directly related to the decision by NATO to launch an Activation Warning order (ACTWARN) to buttress Holbrooke's negotiations, this organizational decision was heavily dependent on the willingness of the U.S. administration to keep the precepts of constructivism alive by "[rallying] international support for an eventual use of force." 65 Now, the negotiators would no longer be under the "influence of foolish idealism."66

Faced with German and French opposition, the United States accepted one final round of talks at the castle of Rambouillet in January 1999. The controversy concerning the content of the Kosovo Interim Agreement, otherwise known as the Rambouillet Agreement, is well documented. Some say it was an agreement specifically designed to be rejected. ${ }^{67}$ Others say it was tantamount to signing a fait accompli. It was, without a doubt, an ultimatum. It was at this moment that the international community moved from being a mediator to a participant to the dispute. ${ }^{68}$ It was at this moment that great powers and institutional actors presented themselves in such a way as to impose an in-

61 Judah, “Kosovo’s Road to War,” 12.

62 Skrpec, "European and American Reactions to Kosovo," 95-96.

63 Stephen P. Aubin, “Operation Allied Force: War or 'Coercive Diplomacy’?” Strategic Review (Summer 1999): 4.

64 Filip Tesar, "What Has NATO Achieved in Kosovo?" 53.

65 Skrpec, "European and American Reactions to Kosovo," 103.

66 Tesar, "What has NATO Achieved in Kosovo?”, 53.

67 Judah, “Kosovo’s Road to War,” 14.

68 Marc Weller, “The Rambouillet Conference on Kosovo," 222-23, claims that the U.S.-EURussia Contact Group would "hold both sides accountable if they fail to take the opportunity now offered...," and the North Atlantic Council, on 30 January 1999, threatened that NATO was ready to "take whatever measures are necessary... to avert a humanitarian catastrophe." 
stitutional framework for the management of the Kosovo crisis. Judah's interpretation seems incomplete compared to the detailed account given by Marc Weller. On 23 February 1999, the Serb delegation and the Kosovo delegation had almost agreed on a text which was, to the Serbs, the launching pad for further negotiations two weeks later. At that subsequent conference, the Serbs produced a counterproposal that attempted to reopen matters that had been deemed non-negotiable by the Contact Group. In other words, the Rambouillet Agreement was not so difficult to accept, given that talks broke down so late in the game. The only event that permits an analyst to think that the international community, NATO, and the U.S. in particular "engineered" the failure of negotiations came when the Kosovo delegation was encouraged to wait for Serb comments on a final text (comments which took the form of the counterproposal described above).

Otherwise, it was the Serb side that took every opportunity to delay the process, and to sabotage the talks. ${ }^{69}$ Yet the Rambouillet Agreement is a statement saying that the territorial integrity of the FRY would be preserved, that refugees would be authorized to return, that their fundamental rights would be respected, but that the implementation of this plan would be overseen by interlocking international institutions, including humanitarian organizations. As I have mentioned previously, only one concept enumerated above qualifies as worthy of the traditional understanding of the state, and corresponding to a realist constructivist perspective. The other concepts of human rights and institutional stewardship refer directly to a liberal constructivist approach.

When the Kosovar Albanian delegation very reluctantly signed the document (Dr. Rugova had lost much of his clout to the KLA by that time) and when Serbia walked out, the end result was that the minority side was in fact accepting the territorial integrity of the FRY and agreeing to guarantees to the majority party's rights. The Kosovar Albanians were seemingly the losers, because they were signing away their dreams of independence. But it was a case of choosing the lesser of two evils: stick to the plan for independence and be wiped clean from Kosovo by Serb forces, or sign it away, and survive under the protection of KFOR. By signing, the Kosovo Albanians were ratifying a legal construct of a realist nature. If Serbia had signed, it would not only have been acceding to a legal construct corresponding to its realist perception of statehood, but it would also have been signing for liberal constructivist ones as well. The fact that the Serb delegation walked out not only meant that it was against the idea of having NATO troops stationed to enforce the work of the OSCE, UNHCR, and the UN; it also meant that it did not recognize the work of these organizations as legitimate, and that it rejected the principles, rules, and norms under which they were created and continued to function. ${ }^{70}$ It preferred the logic of power. ${ }^{71}$

69 Marc Weller, “The Rambouillet Conference on Kosovo,” 233-35.

70 This aim was explicit in Madeleine Albright's plea to the Senate Appropriations Committee on Foreign Relations, made 20 May 1999, to make the United States "innovators and trailblazers, builders of new institutions and adapters of old."

71 Judah, “Kosovo’s Road to War,” 14. 
When NATO launched military actions against Serbia in late March 1999, it was retaliating against a perception of international relations that threatened the fragile cooperative security architecture that was emerging in the post-Cold War environment. According to U.S. Secretary of State Albright, "Milosevic's use of violence and terror poses a profound threat to the security and character of Europe."72 NATO's "humanitarian war" was simultaneously the application and protection of liberal constructivism; this organization and its members were defending their region against the possibility of egotistic self-help in international relations, the prospect of which could unravel the Alliance. After all, Europe was proving incapable of mustering an adequate response to deal with Milosevic, even though it had set out in the "Petersberg Tasks" in 1992 what humanitarian catastrophes would be deemed worthy of intervention and how that intervention would occur. ${ }^{73}$ No international organization or group of actors seemed able to stem the rising tide of predatory realism, and so force had to be applied against a state (Serbia) and one of its provinces (Kosovo) whose identity was deemed detrimental to the survival of the system of international relations that had helped keep the peace in Europe for fifty years. Adam Roberts writes that there was no "obvious alternative course of action” but force, since cooperative accommodation was being resisted.$^{74}$ Cooperative accommodation, which implies respect for the norms, rules, and laws that support international relations in a constructive framework, is deemed to function best when membership is as universal as possible. The object becomes to change the identity (very often the regime or leadership) to make sure that the state in question becomes able to integrate into the international institutions that make the peaceful settlement of disputes possible, much like a hockey player must conform to different standards when he walks onto a golf course. ${ }^{75}$ As Adam Roberts writes, "The available evidence suggests that the critical considerations impelling NATO to take action were those of humanity and credibility.",76

\section{Operation Allied Force}

Most NATO powers have chosen to frame their decision to intervene Kosovo through what can only be termed a constructivist understanding of international relations. Even the way in which NATO took action speaks of the respect that member states had for NATO's rules of procedure (which, admittedly, irritated more pragmatic Americans).

72 U.S. Secretary of State Madeleine K. Albright's Statement before the Senate Appropriations Committee on Foreign Relations, 20 May 1999.

73 Petersberg Declaration, adopted at the Ministerial Council of the Western European Union (WEU), June 1992; available at www.weu.int.

74 Adam Roberts, “NATO’s ‘Humanitarian War’ over Kosovo,” Survival 41:3 (Fall 1999): 104.

75 Elton Atwater, Kent Forster, and Jan S. Prybyla, World Tensions: Conflict and Accommodation, $2^{\text {nd }}$ ed. (New York: Meredith, 1972), 355. On integration, and the realist-constructivist divide, see Frederic Labarre, "Regional Integration through the Stability Pact," in The Stability Pact for South East Europe-Dawn of an Era of Regional Cooperation?, ed. Predrag Jurekovic (Vienna: National Defense University, 2002), 130. Adam Roberts, “NATO’s ‘Humanitarian War’ over Kosovo,” 109. 
I will not discuss here the details of the air campaign and its attendant controversy, which have been covered at length elsewhere. It is nevertheless necessary to summarize that the air campaign did not produce results rapidly enough for NATO; the option for escalation was always present, and it was used. Operation Allied Force was not war. Rather, it was figured as a "pattern of diplomacy backed by force" reflecting "a combination of escalation theory and high-tech attrition warfare-minus the casualties (ours, that is) ... designed to signal the enemy first, and gradually wear him down if he did not yield early on. Moreover, it had the benefit of being acceptable to all nineteen members of NATO." ${ }^{, 77}$ This consensus was bought at the price of heavily criticized high-altitude bombing, ${ }^{78}$ but to Stephen Aubin, this gradualism is only explainable "as part of a conscious decision by NATO political and military leaders." ${ }^{79}$

Gradualism also meant that NATO was reluctant in undertaking the action, not only for its own sake, but also because of the legal conundrum in which it found itself. It did not want to create the impression that it would wantonly launch assaults against any state it deemed to not be respecting human rights within its own borders, or at least launch such an attack as to reduce adversary to complete destruction. Aubin writes that Operation Allied Force was not designed to achieve victory, but to signal that NATO was serious about the pressure it sought to apply. In the end, Serbia was not defeated, but was forced to strike a deal. This approach was essential if Serbia was to remain in a position to integrate in mainstream Europe later on.

Dagmar Skrpec wrote that the European approach to crisis management focused too much on process for the taste of the Americans, who were concerned about the "bottom line." This is rooted in the European preference of using diplomacy to maintain a structural status quo with the current balance of power in Europe, whereas the U.S. is motivated by efficiency. ${ }^{80}$ While this assessment is not inaccurate, the basis for it is. A constructivist approach would see the Europeans' lengthy diplomatic maneuvers as a signal unto itself; it is the message that tells Serbia that it is part of Europe, simply because Serbia is being addressed. The only difference is that a U.S. interpretation would maintain that the identity of this interlocutor is mismatched with that of Europe, so that offers of integration and participation are less efficient (because misunderstood) than the threat of force. As evidenced by the national positions of NATO members regarding their decision to use force (which will be discussed below), it is

77 Stephen P. Aubin, “Operation Allied Force,” 5.

78 Adam Roberts, “NATO’s ‘Humanitarian War’ over Kosovo,” 111-12.

79 Aubin, "Operation Allied Force,” 7. A NATO Parliamentary Assembly resolution stated that "any intervention with the purpose of preventing or ending massive human rights violations can only be the last resort and [...] has to respect the principle of proportionality." Heinz Gärtner, "European Security, the Transatlantic Link and Crisis Management," in Europe's New Security Challenges, eds. Gärtner, Hyde-Price, and Reiter (Boulder, CO: Lynne-Rienner, 2001), 130, quoting a NATO Parliamentary resolution made at Amsterdam, 15 November 1999.

80 Skrpec, “European and American Reactions,” 106-7. 
clear that a constructivist explanation is more fruitful than one that relies on the balance of power, especially since Serbia was never in a position to threaten it.

NATO as an organization does not "decide" to declare war. It is the combined and consensual decision of all its members that permit it to take military action. Although there is evidence that the United States had grown tired of what it perceived as useless diplomatic overtures to the Milosevic regime and had become more adamant that force should be used, it cannot be said that the United States imposed their unilateral decision through the North Atlantic Council. Rather, "the Alliance can be conceived as a mechanism for helping to codetermine the American 'national interest,' with the result being that the latter resembles a collective (Western) interest that is constituted from a Western 'identity' and set of shared values."

Therefore, it cannot be said that the Alliance is the tool of even the more powerful of its members. For example, "Canadian policy makers [and opinion shapers] have seen in the 'new' NATO a tool that promises to fulfill the loftier purposes once associated with the United Nations." ${ }^{82}$ For Canada, the UN's purpose is also associated with Canada's contemporary interests of promoting "human security." ${ }^{, 3}$ More "realistically," however, Canada equates European stability with national security. The constructivist element of Canadian policy emerges by virtue of its firm commitment to the UN and NATO as international organizations, which is reflected in the National Defense Act. So if European stability is (ill-)defined as a vital interest of Canada, our "obligation" to participate in the Kosovo war nonetheless has the effect of buttressing Alliance policies $;^{84}$ our laws perpetuate international institutionalism, not as an indictment of realist thinking, but as a profession of liberal constructivism. Not participating in the Kosovo campaign would have been to act "out of character," at odds with Pearsonian idealism, and with our own identity, which is determined by values, ideas, and standards of conduct. The Canadian motivation to participate "reveals little support for what might be thought of as the classical concern of realism in international politics.",

In the United Kingdom, Prime Minister Blair's "ethical foreign policy" called for a "doctrine of international community" that saw an exception to the rule of non-inter-

${ }^{81}$ David G. Haglund, “Allied Force or Forced Allies? The Allies' Perspective,” in Alliance Politics, Kosovo and NATO's War: Allied Force or Forced Allies?, eds. Martin and Brawley

82 (Basingstoke, Hamps.: Palgrave, 2000), 92.

Ibid., 103.

See www.humansecurity.gc.ca/menu-en.asp. See also Steven Wallace Lowe, Peacekeeping, Peace building, Human security and Self-interest: Why Canada Remains the Foremost Peacekeeper, notes to the $3^{\text {rd }}$ Annual Graduate Studies Symposium of the Canadian Defense Associations Institute, 4 Nov. 2000; available at www.cda-cdai.ca/symposia/2000/lowe.htm (accessed 8 January 2007).

84 lower," in Alliance Politics, Kosovo and NATO's War: Allied Force or Forced Allies?, 187. Ibid., 194. Richard Nossal and Roussel also emphasize the multi-party consensus over the humanitarian emergency that Kosovo represented, thus reinforcing the notion that a government's predisposition to act for non-power related issues is identity-based. This strengthens the notion that constructivism is a more powerful explanatory tool for the Kosovo War. 
ference if the international community was convinced of its case for intervention, if diplomacy had been exhausted, if military action were proportional, if the participants could see it through to the finish, and lastly if national interests were involved. ${ }^{86}$ The U.K. gave three reasons to act-including the protection of NATO credibility, so popular to critics of the intervention-but even more convincing than the maintenance of the special relationship with the United States was the moral imperative that "barbarity cannot be allowed to defeat justice." ${ }^{87}$

In other words, the rule of law must not yield to anarchical pressures, or to a system of relations, habits of behavior that could reintroduce the realistic constructivism of self-help. The urge to protect norms of humanitarian conduct was as strong as that of protecting the national interest, or rather, Labour Party policy in the U.K. meant that protecting humanitarian conduct was equal to the national interest; after all, Great Britain had sought to secure the respect of other nations through its contributions to keeping the peace and promoting democracy. ${ }^{88}$ The strategic and moral considerations found themselves to be mutually reinforcing.

In Germany-a nation whose current identity is very much defined by its World War II and post-War experiences-one could expect a neutral stance, yet the political climate in the late 1990s favored a strong commitment to human rights, which made it impossible to back down when it became clear that diplomacy was useless in response to Milosevic. As Peter Rudolf notes, "If the war had not been fought for 'moral values' but for traditional 'national interests' such as oil or national stability, domestic resistance to German military participation would have been much greater and politically more effective." 89

Another indicator suggesting a liberal constructivist approach was Germany’s preference for the use of multilateral institutions during the Kosovo crisis. This had the effect of demonstrating to friend and foe alike that Germany was not falling back into a self-help attitude. This was not a foregone conclusion, given Germany's hasty recognition of Croatian independence in 1991 (without due consultation with other European and Atlantic partners) and the evidence that the former East Germany was more hostile to humanitarian intervention (which suggests a different degree of integration of Western values). ${ }^{90}$

France's backing, however, was fragile and confused, which is normal in the context of a strategic role reassessment. Already one of the principal leaders of Europe, it had only recently (1996) returned to the NATO fold after an absence of thirty years. These were years of defense self-sufficiency, where the traditional features of state sovereignty were still operating side-by-side with the elevation of a typically European

86 Louise Richardson, "A Force for Good in the World? Britain's Role in the Kosovo Crisis,” in Alliance Politics, Kosovo and NATO's War: Allied Force or Forced Allies?, 149. Ibid., 160.

88 Ibid., 158-59.

89 Peter Rudolf, “Germany and the Kosovo Conflict,” in Alliance Politics, Kosovo and NATO’s War: Allied Force or Forced Allies?, 132.

90 Ibid., 136-37. 
solution to its regional problems. It is not surprising, therefore, that France in general conceived of the war as a "battle for a certain conception of Europe and European values, for human rights, even for European civilization."91

Of all the countries that intervened in Kosovo, France's participation, rationale, and behavior were the most consistent with a realist understanding of international relations, and thus it is the only example that can come close to invalidating the claim that liberal constructivism is the most potent explanation for the Kosovo war. French foreign policy is aimed at greater multilateralism and multipolarity. Intrinsic to these two apparently antithetical terms is the notion of balancing against the current hegemon, but by enlisting the help of international organizations. Little wonder, then, that it sought to limit what it saw as U.S. unilateralism and NATO predominance by giving added weight to UN participation in the conflict.

Can we therefore convincingly claim that France was acting in a realist fashion when its primary bone of contention with the U.S. was to ensure that the UN remained the "ultimate source of international law and legitimacy for the use of force"? ${ }^{92}$ At best, we can speak of a balance of institutions, not a balance of power. The liberal constructivist motivations behind France's participation seem best represented by the fact that "backing for NATO action appeared emotional, inspired by the news and pictures of massacres and streams of refugees, rather than political."93

Such a decision may have been an awkward one to make at a moment when France was attempting to deepen European integration, but the way it behaved was consistent with its stated policy of maintaining French influence, using international organizations in collective decisions (as they are no longer a constraint, but a facilitator of policy), using IOs for their own sake, initiating norms, and defending European identity (rather than directly defending national interests). French decision-makers have come to the conclusion that foreign policy cannot be confined to interstate diplomacy; it now goes for institutions, in particular the EU and the UN. ${ }^{94}$ There can be no doubt that power considerations are always at the forefront of French foreign policy thinking, but it does not detract from a strong institutionalist and functionalist component. Realism is therefore not the adequate framework with which to explain French policy decisions.

Two other exceptions stand out, which either have no impact or work to reinforce the interpretive power of the liberal constructivist explanation of the Kosovo war. Italy's participation was more directly related to its national interests, because the flood of refugees from the conflict would ultimately materialize on its shores, as it did in the wake of the Albanian financial collapse of 1997-98. But it is also well known that reputation acquires material significance in Italian behavior, and so being seen as a credible participant in NATO was always important to retain international legitimacy as an actor in international and European affairs. But the fragmentation of public

\footnotetext{
91 Alex McLeod, "France: Kosovo and the Emergence of a New European Security," in Alliance Politics, Kosovo and NATO's War: Allied Force or Forced Allies?, 117. 
opinion and of political life (Italy has notoriously fragile and unstable coalition governments) has meant that the decision to participate, the manner in which to participate, and how to rationalize that participation was directly related to Massimo d'Alema's desire to maintain his governing coalition intact. A motion explaining Italy's position that was passed on 26 March 1999 sought to reassure public opinion, avoid the alienation of the Italian Communists (who maintained strong ties with Moscow-always helpful if the Soviets had won the Cold War), and to signal to the pacifists that NATO's intentions were not to obliterate Belgrade, but bring it to the negotiating table. ${ }^{95}$ Italy's posturing thus had less to do with the ethical principles of humanitarian intervention than the survival of a chronically paralyzed government.

Spain, by contrast, found itself militating in favor of the Kosovo campaign also for reasons of reputation. Whereas the general Spanish public was admittedly cold to the idea of intervention (the parallel between the Kosovo and Basque situation was uncanny), Jose Maria Aznar's government seemed eager, according to David Haglund, to be counted among Europe's major powers, and—as if he knew that this meant adopting features of continental identity-reproduced essentially the same discourse as that deployed by other great powers (Britain, in particular).$^{96}$ So again, the notion of national interest did not find a policy expression in the traditional sense, but rather the attraction of shared European values held sway - or, rather, to be counted among those sharing those values was deemed a prize unto itself. This gives added weight to the notion of a constructive understanding of the Kosovo War.

By far the most heavily criticized member of NATO to participate in the air campaign was the United States. Having shouldered most of the burden, pundits were quick to point to a U.S. hegemonic strategic drive in the Balkans. Even here, it seems, the pundits can be proven wrong. There is no doubt that the fact of contributing more than all the other Allies combined generates its own rewards and comes with privileges. But it is striking, in hindsight, to see how the U.S. did not translate these privileges and advantages into absolute gains, as realist theory would have predicted. ${ }^{97}$

What were the American motivations for engaging in the Kosovo war? Charles Kupchan paints a growing isolationist portrait of twenty-first century America, hinging on the fact that novice policy-makers will not have had first-hand experience of World War II or the Cold War, unlike Secretary of State Madeleine Albright (whose family fled Nazi-occupied Czechoslovakia), who was adamant that Milosevic "should not be allowed to do to Kosovo what he got away with in Bosnia." Changes in U.S. policy thus have less to do with external developments than with internal demography. It is for this reason that the American public - represented by its Congress - was uneasy

95 Maurizio Cremasco, "Italy and the Management of International Crises," in Alliance Politics, Kosovo and NATO's War: Allied Force or Forced Allies?, 171-72.

96 David G. Haglund, “Allied Force or Forced Allies? The Allies’ Perspective,” 104-7.

97 In fact, it is the experience of the Kosovo air war (and the way the campaign was waged) that is most often given as a reason for President Bush's refusal to acknowledge the Article V help offered by NATO on 12 September 2001, and the movement of "transformation" of the Alliance ushered in at the November 2002 Prague Summit. 
about foreign adventures in Bosnia and Somalia. The activism of Clintonian foreign policy was at odds with the changing identity of the United States. The end of the Cold War had promised a peace dividend, following which the United States could take care of its own backyard (the North Atlantic Free Trade Agreement is a testimony to this care), while Europe would take care of its own. The United States knew that not only was the rest of the planet weary of their hegemony, but also that if internationalism were to triumph, the United States would have to let international organizations take the lead. Stephen Walt mentions that this attitude changed during President Clinton's time in office and approached traditional realpolitik. But this is hardly an indictment of constructivism by stating that the United States had a habit of "relying on international institutions when they suit U.S. purposes or criticizing or ignoring them when they do not." ${ }^{98}$ Such an argument still demonstrates that notions of power and dominance are not exogenous to states, but are the product of social choices within societies.

Even though Walt, a realist, is eager to show that his preferred theory prevailed in the waning years of Clinton's presidency (which happened to coincide with the Kosovo war), he nevertheless argues that it was failures in humanitarian intervention like the effort in Somalia that paved the way for even grosser omissions in Rwanda and, finally, contributed to a hesitant stance over the war in Kosovo. Walt forgets to mention that the public aversion at launching a military action against Serbia could not have been overcome had the Clinton Administration decided to intervene unilaterally (that is, outside of multilateral structures). The administration became personally committed to intervention in great part because of the key players' past experiences. ${ }^{99}$

Here, therefore, there seems to be a mismatch between how U.S. interest is perceived by the public (a preference for non-intervention, or at least heavily conditional intervention) and the Clinton Administration's "assertive multilateralism," motivated by the desire to promote human rights and rule of law. This is where constructivism is better supplanted by leadership theories. U.S. identity should drive its interests, in constructivist parlance. If the Clinton Administration had enunciated an interest (lukewarm at best, but this was motivated by domestic constraints as much as by the need to not be perceived as an overbearing hegemon) towards humanitarian intervention, it was still a feature of liberal constructivist policy-making. Mr. Clinton had to use NATO as a tool of intervention; not doing so would have meant seeking authority from Congress (which he clearly would not have received, considering the American public's predisposition). U.S. Representative Ron Paul's testimony to Congress would seem to support the notion that international organizations are instrumentalized for U.S. interests,

98 Stephen M. Walt, “Two Cheers for Clinton’s Foreign Policy,” Foreign Affairs (March/April 2000): 77. See also Ivo H. Daalder and Micheal O’Hanlon, "Unlearning the Lessons of Kosovo,” Foreign Policy Online (Fall 1999); available at www.brookings.edu/views/articles/ daalder/19990920FP.htm. Daalder and O’Hanlon quote National Security Adviser Sandy Berger saying that future humanitarian intervention would be weighed against national interest priorities.

99 Matt Welch, “Temporary Doves,” Reason Magazine (May 2004); at www.reason.com/news/ show/29124.html. 
but clearly, in this case, interests had nothing to do with power in the realist sense (despite what the critics say):

This war is illegal. It is undeclared. There has been no congressional authorization and no money has been appropriated for it. The war is pursued by the U.S. under NATO's terms, yet it is illegal even according to NATO's treaty as well as the U.N. charter. The internationalists do not even follow their own laws and do not care about the U.S. Constitution. ${ }^{100}$

Charles Kupchan assessed President Clinton's response as a happy medium, "authorizing an air campaign and nothing more," knowing that "failure to confront Milosevic over Kosovo would likely jeopardize Macedonia and the whole Balkan peninsula." ${ }^{101}$ Clearly, this assessment is true, but lacks nuance. Failure to confront Milosevic would have also represented a threat to Euro-Atlantic identity, and to shared Euro-Atlantic norms and values. In the end, liberal constructivism remains the most potent explanation for the Kosovo war. Clinton's policy shows that "Americans do not like to think of themselves as practicing realpoliticians, but they do like being number one."102

It is no surprise, then, that the 2006 NATO Handbook summarized the Kosovo campaign as one where the international community was concerned about the risk of conflict contagion, the humanitarian consequences, and Mr. Milosevic's disregard for diplomatic initiatives to resolve the issue. ${ }^{103}$ The international community (here wearing its NATO hat) had resolved to confront the Milosevic regime because of humanitarian reasons, and not out of a desire for a power grab. Whereas the level and quality of military involvement varied from country to country, this can be blamed on domestic constraints. The underlying policy was one of preservation of multilateral conflict resolution capacities and institutionalism in a bid to stave off widespread temptations to return to a self-help system of international relations.

It would not be going far out on a limb to say that NATO nations understood the implications of this conflict not as one that threatened their security or access to strategic resources, but one that threatened stability in the "new world order" dictated by obedience to cooperative/associative norms of behavior. In support of the earlier claim that both Serbia and the Kosovar Albanians were operating under clearly dissociative realist norms is NATO's policy of pointing the finger of blame at both protagonists. ${ }^{104}$ It is only by adopting the language of power that the Milosevic regime could be forced to reverse its policies. The other indicator suggesting that the international community could have its way can be found in the current protracted discussions about the status

${ }^{100}$ Statement by the Hon. Ron Paul (R-Texas) to Congress, 5 May 1999, Congressional Record 1999, H2779.

${ }^{101}$ Charles A. Kupchan, “Kosovo and the Future of U.S. Engagement in Europe,” in Alliance Politics, Kosovo and NATO's War: Allied Force or Forced Allies?, 77.

102 Stephen M. Walt, “Two Cheers for Clinton's Foreign Policy,” 79.

${ }^{103}$ NATO, Handbook (Brussels: Office of Information and Press, 2006), 149.

104 Ibid. 
of Kosovo. Though this is not within the scope of this essay to analyze, it is nevertheless useful to remember that UN resolutions (and international organizations, up to the point of the Rambouillet documents) stressed at every turn the territorial integrity of Serbia - that is, that Kosovo would not find statehood in the internationalization of the dispute that opposed it to Belgrade. In other words, NATO's air campaign over Kosovo was a representation of institutional anger at having two communities defy the principles, rules, and norms that guide international and intranational behavior.

\section{Intervention in Kosovo: Catch-22}

Heiko Borchert writes that "joint liberal and democratic norms safeguard democratic peace, and Europe's security organizations contribute to the establishment of such norms at the domestic and international levels." He continues by saying that "Europe's security organizations strengthen national democratic norms [by broadening] the protection of human rights." 105 Yet neither NATO nor OSCE rules authorize military intervention for humanitarian principles, this being the exclusive privilege of the United Nations, through its Security Council and its Charter. ${ }^{106}$ Heinz Gärtner has recommended that large international organizations like the OSCE and the UN be the source of legitimacy for crisis management operations. ${ }^{107}$ In the case of Kosovo, the OSCE displayed its customary incompetence, and the UN Security Council found itself paralyzed. Katarina Saariluoma and others, on the contrary, have successfully argued that customary international law was sufficient as a basis for Operation Allied Force. ${ }^{108}$ Nevertheless, the strong desire to legitimize the air war after the fact seems suspect. As Martha Finnemore puts it, "Realists or neoliberal institutionalists might argue that in the contemporary world, multilateral behavior is efficient and unproblematically selfinterested because multilateralism helps to generate political support both domestically and internationally for intervention."109

If democratic peace is safeguarded by norms, how can these norms themselves be safeguarded? Because these norms are established by international institutions, it follows that it is the institutions themselves that need to be preserved. As Sean Kay writes, "The credibility of NATO's institutional adaptation became a critical, if not the

${ }^{105}$ Heiko Borchert, “Strengthening Europe’s Security Architecture: Where Do We Stand? Where Do We Go?”, in Europe's New Security Challenges, 169.

${ }^{106}$ Ibid., 172-73. See also Martin Smith, On Rocky Foundations: NATO-UN Cooperation (Bradford, U.K.: Bradford University Press, 1994) on the subject of NATO support for UN SC mandates.

${ }^{107}$ Heinz Gärtner, “European Security, the Transatlantic Link and Crisis Management,” 145.

${ }^{108}$ Katarina Saariluoma, Operation Allied Force: A Case of Humanitarian Intervention?, Athena Paper \# 1 (Garmisch-Partenkirchen: Marshall Center, 2004), 61-75. See also David M. Ackerman, “Kosovo and NATO: Selected Issues of International Law,” in Kosovo-Serbia: A Just War?, ed. Frank Columbus (Commack, NY: Nova Science Publishers, 1999), 155-66.

${ }^{109}$ Martha Finnemore, “Constructing Norms of Humanitarian Intervention,” in The Culture of National Security: Norms and Identity in World Politics, ed. Peter J. Katzenstein (New York: Columbia University Press, 1996), 183. 
critical, reason that its members chose to fight a war through the institution as opposed to pursuing a coalition of the willing." ${ }^{110}$ Thomas Risse-Kappen makes a strong effort at explaining why NATO has survived the end of the Cold War. On one hand, it has adapted to the new environment. While this may be a feature of bureaucratic theory, another interpretation may hold that the threat perception is heavily dependent on a value structure that is alien to the Alliance. In this sense, NATO has not changed. Just as the "Soviet domestic structure and values ... were regarded as alien," the behavior of Serbia was seen as roguish, and it is this behavior that is the threat. ${ }^{111}$ NATO's adaptation has to do with even denser institutionalization, particularly with its former adversaries in Central and Eastern Europe and the former Soviet Union, and this is seen as a defense of the identity of the Alliance members. There can be no projection of power without a corresponding projection of values and forms of society, "hence the changing Western agenda of international politics, aid, humanitarian intervention, economic development.... The powerful idea of sovereignty as a barrier between the domestic and international realms is under growing challenge."112

Without a UN mandate, NATO (that is, the sum of its parts) chose to protect rulesbased international relations. If it had respected UN authority in the first place, it would have created a "modern precedent," signaling to the world that it intended to stand by as the Milosevic regime and the KLA went head-to-head. This would have been a signal that the principle of non-interference, which is based in the realist respect for state sovereignty, is held in higher regard than the principles of respect for human rights instituted by the OSCE, the UN, and its agencies. It would have been an acknowledgement that the vision of a New World Order could give way to the "business as usual" of Machiavellian realpolitik.

\section{Conclusion}

Martha Finnemore has written that "the international normative structure is created by and serves the most powerful. Humanitarian action generally, and humanitarian intervention specifically, do not obviously serve the most powerful." "113 This statement is patently applicable to the conflict between Serbia and its Albanian minority. Without a local normative structure, the protagonists could only "serve themselves" through selfhelp. Seeing the asymmetry of the situation, the Kosovars' only recourse was to internationalize the dispute.

This essay has demonstrated that the multilateral attempts at solving the dispute were a convincing indication that liberal constructivism was at work at the moment when Europe and the United States attempted to resolve the dispute diplomatically. Anne Deighton has perfectly illustrated how international institutions drove policy

\footnotetext{
${ }^{110}$ Sean Kay, “NATO, the Kosovo War and Neoliberal Theory,” 259; italics mine.

111 Thomas Risse-Kappen, "Collective Identity in a Democratic Community: The Case of NATO,” in The Culture of National Security: Norms and Identity in World Politics, 395.

112 John Williams, Legitimacy and the Rise and Fall of Yugoslavia, 43.

113 Martha Finnemore, “Constructing Norms of Humanitarian Intervention,” 187.
} 
around Kosovo. The OSCE, NATO, the EU, and the UN together made liberal constructivism operationable. ${ }^{114}$ Most of these institutions function by consensus, which is the fruit of the collective and sovereign decisions (in the Westphalian/Weberian modern sense) of members. Those decisions would be impossible outside the legal rules and other norms under which their relations are based. Such rules and norms would not have been agreed to, nor kept in force without the interest to do so-interests that are based on a shared identity. The defense of interest becomes equated with the defense of identity. In that sense, it becomes irresponsible to say "no existential threat has existed in Europe on a continental scale since the end of the Cold War."115

Obedience to cooperative norms and rules, multilateral international relations, and the defense of issues that are not traditionally of the realm of power politics-what we have called here "liberal constructivism"-is characteristic of post-modern states and groups of states. But, in contrast, some modern states still hold traditional norms of sovereign independence and non-interference as superior to the pressures of respect for human rights. Russia, China, North Korea, and Iran are all modern states by that definition, and it is no surprise that some of these gave aid and comfort to Serbia (also a modern state) during the Kosovo crisis. "Realist constructivism" being the framework of choice in modern states to understand and practice international relations, I argue here that the identity of post-modern states is always under threat when, in their geographical region, different norms and rules of behavior operate.

When NATO was selected as the agent that would be used to correct the behavior of Serbia, it found itself facing a dilemma that had been in the making since the end of World War II. The corpus of international law is embodied mostly in the charters of multilateral institutions created during the Cold War, when all the signatories agreed to the content (all of them being "modern" states) and referred to realistic principles of international relations, such as non-interference, balance of power, etc. Such charters codified what a state does in reality. But a significant part of international law also became codified when these international institutions became free from the embrace of the Cold War. This portion of the corpus of law remains post-modern in essence; it codifies what states would do in an ideal world.

As was stated at the outset of this essay, some states have remained modern, and others have become post-modern. I have shown that many a national public was appalled at what was happening in the former Yugoslavia, and so political survival for many a post-modern regime meant intervention. While the political persuasion of such regimes (center-left) can be invoked as a partial explanation for the decision to intervene, the intervention itself was seen by many as illegal. Yet, as we have argued, had NATO not done anything (and the Alliance was quick to point out the need for a doctrine of humanitarian intervention), not intervening would have threatened the validity

${ }^{114}$ Anne Deighton, “The European Union and NATO’s War over Kosovo: Towards the Glass Ceiling?”, in Alliance Politics, Kosovo, and NATO's War: Allied Force or Forced Allies?, 57-75.

115 Carlo Jean, “Arms Control in Transition: Building a New Security Order,” in The Future of Arms Control Agenda, ed. Adam Rotfeld (Oxford: Oxford University Press, 2001), 120. 
of liberal constructive norms and rules of behavior. In a world also composed of premodern states, minorities lacking the most basic protections of the central government would have fallen victim to the depredations of more aggressive groups, and the sad story of UN peacekeeping failures in the Balkans, Rwanda, Somalia, and others lesser known (Chechnya, Nagorno-Karabakh, Timor, etc.) would have become common occurrences in the post-Cold War world. NATO had to go by the widest possible interpretation of its Article I, where the

Parties undertake, as set forth by the Charter of the United Nations, to settle any international dispute in which they may be involved by peaceful means in such a manner that international peace and security, and justice, are not endangered, and to refrain in their international relations from the threat or use of force in any manner inconsistent with the purposes of the United Nations.

Peaceful diplomatic means and economic incentives having been exhausted, NATO members saw that refraining from the use of force would have catapulted the nature of international relations back to self-help norms. If these norms assumed their previous place of precedence in international life, post-modern identities would have been lost and, in this sense, national interests would have been under threat. Also, not acting would have weakened Article II of the North Atlantic Treaty, where the Parties must

contribute to the further development of peaceful and friendly international relations by strengthening their free institutions, by bringing about a better understanding of the principles upon which these institutions are founded, and by promoting conditions of stability and well-being....

This article is the only one of the NATO Charter that bears any post-modernistic inclinations. NATO could have sat this one out, its members shielding themselves behind Article VII, which claims that the UN Security Council is the ultimate arbiter of the use of force in international relations (but the UNSC being occupied by two modern states that hold veto power, the minority on the Security Council would effectively hold hostage the existence of the many post-modern member-states of NATO, as well as other European states seeking to escape the Hobbesian world of the war of all against all, and push them to frame their relations in a Kantian way). Finally, the urgency with which several NATO members rushed to reassure the world that the intervention was an isolated case further indicates the acuteness of the perception that it could have been a façade for realist depredation. In the end, not only did the countries promoting liberal constructivist policies have to violate the very rules they swore to protect to enable the survival of liberal constructivism, they confirmed their identity as holders of such values by a public nostra culpa of their disobedience to the UN Security Council. 


\section{THE QUARTERLY JOURNAL}

\section{Bibliography}

Ackerman, David M.. "Kosovo and NATO: Selected Issues of International Law." InKosovo-Serbia: A Just War?, 155-66. Commack, NY: Nova Science Publishers, 1999.

Atwater, Elton, Kent Forster, and Jan S. Prybyla. World Tensions: Conflict and Accommodation. 2nd ed. New York: Meredith, 1972.

Aubin, Stephen P.. "Operation Allied Force: War or 'Coercive Diplomacy’?" Strategic Review, no. 4 (1999).

Cabada, Ladislav, and Martin Ehl. "The Kosovo Crisis and the Prospects for the Balkans." Perspectives 13 (1999): 25.

Caporaso, James A.. "International Relations Theory and Multilateralism: The Search for Foundations." International Organization 46, no. 3 (1992): 606-7.

Daalder, Ivo H., and Micheal O'Hanlon. "Unlearning the Lessons of Kosovo." Foreign Policy Online (1999).

Dandeker, Christopher. "The End of War? The Strategic Context of International Missions in the 21st Century." In Eight Essays in Contemporary War Studies. Stockholm: Förvarshögskolan, 2007.

Dougherty, James E., and Robert L. Pfaltzgraff. Contending Theories of International Relations: A Comprehensive Survey. 5th ed. New York: Longman, 2001.

Final Act, Helsinki 1975. In Conference on Security and Cooperation in Europe. Helsinki , 1975.

Finnemore, Martha. "Constructing Norms of Humanitarian Intervention." In The Culture of National Security: Norms and Identity in World Politics, 183. New York: Columbia University Press, 1996.

Future of Kosovo. Official Journal of the European Communities, 1996.

Gärtner, Heinz. "European Security, the Transatlantic Link and Crisis Management." InEurope's New Security Challenges, 130. Boulder, CO: Lynne-Rienner, 2001.

Gordy, Eric D.. "Why Milosevic Still?" Current History (2000): 100.

Haglund, David G.. "Allied Force or Forced Allies? The Allies' Perspective." In Alliance Politics, Kosovo and NATO's War: Allied Force or Forced Allies?, 92. Basingstoke, Hamps.: Palgrave, 2000.

Handbook. Brussels: NATO, Office of Information and Press, 2006. 
Jean, Carlo. "Arms Control in Transition: Building a New Security Order." In The Future of Arms Control Agenda, 120. Oxford: Oxford University Press, 2001.

Jepperson, Ronald, Alexander Wendt, and Peter J. Katzenstein. "Norms, Identity, and Culture in National Security." In The Culture of National Security: Norms and Identity in World Politics, 33. New York: Columbia University Press, 1996.

Kay, Sean. "NATO, the Kosovo War and Neoliberal Theory." Contemporary Security Policy 25, no. 2 (2004): 252.

Keohane, Robert O.. "Multilateralism: An Agenda for Research." International Journal 45 (1990): 731-64.

Labarre, Frederic. "Regional Integration through the Stability Pact." In The Stability Pact for South East Europe-Dawn of an Era of Regional Cooperation?, 130. Vienna: National Defense University, 2002.

Leurdijk, Dick, and Dick Zandee. Kosovo: From Crisis to Crisis. Aldershot, U.K.: Ashgate, 2000.

Lord, Christopher. "Now America Takes Over." Perspectives 13 (1999): 39-40.

Lowe, Steven Wallace. Peacekeeping, Peace building, Human security and Selfinterest: Why Canada Remains the Foremost Peacekeeper. 3rd Annual Graduate Studies Symposium of the Canadian Defense Associations Institute, 2000.

Machiavelli, Niccolo. The Prince. London: Penguin, 1968.

Mearsheimer, John J.. The Tragedy of Great Power Politics. New York: Norton, 2001.

Permanent Council Decision \#218. OSCE, 1998.

Petersberg Declaration at the Ministerial Council of the Western European Union . WEU, 1992.

Popov, Stefan. "NATO Expansion: From Collective Defence to Collective Security."Perspectives 13 (1999): 66.

Res 1199/1988. UNSC, 1998.

Res 1203/1998. UNSC, 1998.

Resolution 1077 (1996). Strasbourg: Council of Europe, 1996.

Roberts, Adam. "NATO's 'Humanitarian War' over Kosovo." Survival 41, no. 3 (1999): 104.

Security Council Resolution. UN, 1993. 


\section{THE QUARTERLY JOURNAL}

Simonen, Katariina. Operation Allied Force: A Case of Humanitarian Intervention? InAthena Papers. Vol. 1. Garmisch-Partenkirchen: Partnership for Peace Consortium of Defense Academies and Security Studies Institutes, 2004.

Situation of Human Rights in Kosovo. UN GA, 1997.

Skrpec, Dagmar. "European and American Reactions to Kosovo: The Policy Divide Revisited in the Iraq War." SAIS Review 23, no. 2 (2003): 94, 98.

State, Madeleine K. Albrigh. Statement before the Senate Appropriations Committee on Foreign Relations., 1999.

Statement by the Hon. Ron Paul (R-Texas) to Congress. In Congressional Record 1999., 1999.

Study on Enlargement. Brussels: NATO Office of Information and Press, 1995.

Tesar, Filip. "What has NATO Achieved in Kosovo?" Perspectives 13 (1999): 56.

Transcripts from the Milosevic Trial. Hague, Netherlands: International Criminal Tribunal for Yugoslavia (ICTY), 2005.

Troebst, Stefan. Conflict in Kosovo: Failure of Prevention? Analytical Documentation, 1992-1998. Flensburg: European Centre for Minority Issues, 1998.

Vickers, Miranda. Between Serbs and Albanians: A History of Kosovo. London, 1999.

Walt, Stephen M.. "Two Cheers for Clinton's Foreign Policy." Foreign Affairs (2000): 77.

Welch, Matt. "Temporary Doves." Reason Magazine (2004).

Weller, Marc. "The Rambouillet Conference on Kosovo." International Affairs 75, no. 2 (1999): 216.

Wendt, Alexander. "Anarchy is What States Make of It: The Social Construction of Power Politics." International Organization 46, no. 2 (1992): 391-425.

Williams, John. Legitimacy and the Rise and Fall of Yugoslavia. London: McMillan, 1998.

Yesson, Erik. "NATO and Russia in Kosovo." Perspectives 13 (1999): 15. 